\title{
Who Were the Mulūk Fārs?
}

\begin{abstract}
Taking a passage in al-Ișțakhrī as its starting point, this paper presents the Fārs rural elites called mulūk and ahl al-buyūtāt. It argues that these families were the dominant influence in the province, controlling many sources of revenue (including overseas trade routes and agricultural taxes). The main body of the paper is a study of one representative of such a family, Muhammad $b$. Wāṣil al-Hanzalī al-Tamīmī. His pedigree can be traced for more than four centuries, from early Islamic times to the $11^{\text {th }}$ century. Finally, the paper discusses earlier scholarship on this figure, showing serious misrepresentations.
\end{abstract}

Keywords: Fārs; malik; ra’̄̌s; ahl al-buyūtāt; local lordship; aristocracy; castle; taxation

\section{Introduction}

Talking about elites in pre-Mongol Iran or in other parts of the Muslim world generally means talking about military commanders, emirs, or governors, or, on the civilian side of state administration, viziers and clerks. Of these, Muslim scholars are best documented, to the point of producing the famous quote "ulemology is a noble science-at least we have to think so, because it is almost all the Islamic social history we will ever have for this period." A prominent example of this state of affairs is the recent study on Baghdadi elites in the Seljuq period. ${ }^{2}$ In the context of pre-Mongol Iran, but also Iraq and Syria, the urban notables tend to be 'ulamä'.

Thanks are due to Peter Verkinderen and Hannah Hagemann, who read an earlier version of this article and gave valuable comments. Their support is gratefully acknowledged. All remaining shortcomings and errors are mine.

1 Mottahedeh 1975, 495; famously also quoted in Humphreys 1991, 187. It is worth noting the reservations about the period-Mottahedeh has in mind the $11^{\text {th }}$ and $12^{\text {th }}$ centuries, a little later than the focus of the present contribution.

2 van Renterghem 2015, I, 57. The author distinguishes three major fields of elite activities: religious and legal encadrement, government service, and economic activities (which the end are restricted to long-distance trade). Rural elites are not covered in this work.

3 The word "notables" to indicate a group of urban elite persons was first used by Albert Hourani in his "Ottoman Reform and the Politics of Notables", reprinted in Hourani 1981 (first published 1968). See also Gelvin 2006.

Ә OpenAccess. () 2020 Jürgen Paul, published by De Gruyter. (cc) BY-NC-ND This work is licensed under the Creative Commons Attribution-NonCommercial-NoDerivatives 4.0 License. 
This situation is of course due to the available source material. Whereas chronicles and other narrative histories yield information about emirs and viziers (the latter group are also the subject of source monographs), Muslim scholars profit from their own literary genre, the biographical dictionary. This has two forms, general and regional, and scholars appear in both. ${ }^{4}$ In certain cases, this abundant material allows complex prosopographic studies; one of the earliest was Bulliet's book on the notables-he calls them patricians-of Nīshāpūr. ${ }^{5}$ There have been more studies of this kind, Mottahedeh on Qazwin for example. The vast material available for Baghdad made van Renterghem's work possible. ${ }^{6}$ For other well-documented cities, a mix of sources has also allowed detailed studies for longer periods; the best example is Durand-Guédy's monograph on Ișfahān. ${ }^{7}$

This focus means that another social group has remained largely unstudied until the present day. These are the rural aristocrats: large landowners, castellans, and so forth. ${ }^{8}$ They must have been there, and must have played very important roles in their provinces and sometimes on a geographically broader level, but we rarely get more than a glimpse of who they were, what they did, where they came from, how they saw their position in society, and so forth. Mostly, they are not mentioned by name-and thus prosopographic studies are out of the question-but they appear under generic identifications like $r u$ 'as $\bar{a}^{\prime}$, ahl albuyūtāt, and so on, or are described with older Iranian terms such as dihqān. ${ }^{9}$ This plurality of terms confirms the situation sketched in the introduction to this volume: many somewhat fuzzy terms are in use for persons and groups of elite status.

There is no type of source that explicitly deals with rural aristocrats, though there is some overlap with the biographical dictionaries where rural lords appear if they were also Muslim scholars. We may conversely surmise that many scholars were landlords, but the sources do not often talk about such profane things as a man's position in society when they can instead give long lists of whose hadith he heard and to whom he transmitted. ${ }^{10}$

\footnotetext{
4 For a recent review of the state of the art, al-Qāḍi 2009.

5 Bulliet 1972. See also Mottahedeh 1975.

6 Mottahedeh 1973.

7 Durand-Guédy 2010.

8 Paul 2016, and for the ra'îs as a type of rural notable, Paul 2015.

9 For this stratum of the elites, see Tafażżoli and Paul 2013. Articles from the Encyclopedia Iranica are quoted exclusively with reference to the online edition.
}

10 Cohen 1970. 
Despite this, since we know that the rural lords must have been a decisive part of the upper class we should endeavor to find out more about them. There are two ways to do so. First, the extant corpus of narrative and non-narrative sources must be scrutinized and the tiny bits of information available there put together. Second, the exceptional passages where rural lords are focused upon must be identified. One of these exceptional passages can be found in al-Iștakhrī’s geography, and it concerns the mulūk ("kings") of his home province, Fārs. ${ }^{11}$ He also writes here of the ahl al-buyūtāt ("noble houses"), another type of rural lord whose position probably was one step below mulūk status; mulūk commanded greater wealth and were eligible for high offices to which ahl al-buyūtāt apparently had no access. It is interesting to note that the mulūk families were all of Arab stock whereas the ahl al-buyūtāt descended from Iranian nobles.

Al-Ișțakhrī knew this province very well. The people he was writing about were active within living memory, and some of their families still held very much the same positions their ancestors had. I suspect that he included this passage in order to show that important people and families came from Fārs-the enumeration of the provincial mulūk is part of the province's fad $\bar{a}$ 'il, part of his praise of it. He may be exaggerating, but only a little; at least some of the events, persons, and families he speaks of can be identified in other sources. The passage in question does not resurface in Ibn Hawqal, who otherwise follows al-Ișțakhrī closely, but nevertheless some information on these elites can also be gained from his work. ${ }^{12}$

In this article, I shall first give examples of the use of the term mulūk in sources dealing with pre-Mongol Iran, before presenting the passage in al-Ișțakhrī in some detail, and finally turning to a case study of one of the representatives of the mulūk Fārs: a man called Muhammad b. Wāṣil b. Ibrāhīm al-Ḥanẓalī al-Tamīmī, whose career in Fārsī politics can be followed between ca. 255 H/869 CE and ca. $262 \mathrm{H} / 876 \mathrm{CE}$. This case study includes dealing with the image of Muhammad b. Wāṣil found in earlier scholarship. He would not necessarily warrant the detailed examination presented here, except that he is one of the rare individuals regarding whom such a study is possible. More such individuals could be identified. Here, I regard Muhammad b. Wāṣil as a specimen of his social group-how typical a specimen must be left to future research.

11 Al-Ișțakhrī 1870, 140 - 144.

12 Ibn Ḥawqal 1939 and 1964. 


\section{Mulūk as a Term}

Today, malik means "king” in Arabic. In earlier sources, the meaning is broader and the term applied to different kinds of elite persons and families. The term is used for rural secular notables (as opposed to Muslim scholars), who are large landholders, nobles, aristocrats, and/or local lords. They are more important, wealthier, and have better connections at court than the rural gentry of Iranian extraction, whom the sources more frequently call dahāqin. In some ways, these noble families, the mulūk and the dahāqīn, run the province together. They are central to its administration and to a large degree manage taxation (often as tax farmers). Later, some of these families become known as the province's ru'asā'.

Apart from the passage in al-Ișțakhrī that serves as the starting point for this contribution, a survey yields more occurrences of the term in pre-Mongol sources. A detailed analysis is beyond the scope of this paper; what follows is a cursory summary. ${ }^{13}$

For pre-Islamic times, the term is used for the Persian kings (regional as well as Great Kings), but also the rulers of Rūm, India, and China. For the Arab world, it is interesting to see which groups have mulūk; most prominently, Kinda, but also Himyar and less frequently other groups. There is also mention of mulūk al-Yaman, "kings of Yemen."14 In the following passage, I will concentrate on mulūk from the Islamic period.

Sources from the early Islamic period have an "extensive discussion of the terms used to designate holders of authority." 15 Malik is only one of those terms, but one that is sometimes privileged.

Al-Khațîb al-Baghdādī includes the biography of a singer of the Umayyad period, Ibrāhīm b. Māhān. Describing his career, al-Khațīb notes that Ibrāhīm met caliphs and mulūk. ${ }^{16}$ Since there were no independent regional "kings" in early Umayyad times, what is probably meant are extremely wealthy and well-connected landowners, and in this case not necessarily rural ones. In his version of the

13 I profited from Peter Verkinderen's expertise who ran a search on my behalf in the 'Jedli' toolbox: https://www.islamic-empire.uni-hamburg.de/en/publications-tools/digital-tools/down loads/jedli-toolbox.html. The search was for mulūk, mulūk al-țawā’if, and mulūk al-ațāf. Peter Verkinderen's generous help is gratefully acknowledged here.

14 In the Islamic period, some Arab groups had mulūk. Some of the Arab dynasties of the $10^{\text {th }}$ and $11^{\text {th }}$ centuries are called by this term, e.g. the Mazyadids at Hilla are presented as mulūk alasadiyya. Al-Ḥillī 1984.

15 Marlow 2016, 113-26.

16 Al-Khațīb al-Baghdādī 1931, 6:175. 
biography of Ya'qūb b. Layth al-Ṣaffār (r. 861-879) which also includes 'Amr b. al-Layth, Ya 'qūb’s brother and successor (r. 879-900), Ibn Khallikān gives some details about the 'revolt' of Rāfi' b. Harthama in Khurāsān. In May 896 CE (Rabī' II, $283 \mathrm{H}$ ) Rāfi' sent to the neighbouring mulūk, asking them to help him against 'Amr b. al-Layth. ${ }^{17}$ In this case, apart from landed properties we can suppose that these families also maintained military resources such as castles, retainers and so forth. Al-Muqaddasī has a report about the emergence of Darī (Persian) as the court language in which the main character is one of the local rulers (mulūk Khurāsān). ${ }^{18}$ In al-'Utbī's history of Mahmūd the Ghaznavid, we also meet mulūk Khurāsān, and he speaks of the mulūk Khurāsān wa-așhāab al-juyūsh bihā. ${ }^{19}$ However, Ibn Funduq Bayhaqī informs us that the province has not produced any mulūk, only military commanders. The author regrets that he cannot include a chapter on the province's mulūk; such a chapter, in his words, is a standard feature in regional historiography. ${ }^{20}$ He calls dynasties such as the Tāhirids and the Saffārids mulūk. Ibn Khurdādhbih, on the other hand, has a list of mulūk Khurāsān together with their titles; probably pre-Islamic figures are meant and some may have survived into the early Islamic period. ${ }^{21}$ This also is the way the anonymous Persian Hudūd al- 'älam uses the term. ${ }^{22}$ In the eastern provinces in particular, the regional or vassal kings can appear as mulūk al-atrāf; some of these kings are also included in Ibn Khurdādhbih's list. Such regional dynasties are typical of these mountainous regions (now part of Afghanistan). ${ }^{23}$

Ibn Hawqal offers a list of local and regional rulers in Azerbaijan and the Caucasus whom he calls collectively mulūk al-ațāff. It is interesting to note that the master of the province, Ibn Abī l-Sāj, is also called malik. This yields a hierarchy of local and provincial mulūk. ${ }^{24}$ In this region, the mountainous northwest of Iran, local rulers are often called mulūk. This also applies also to the rulers of Daylam. ${ }^{25}$

The term mulūk al-ațrāf could be used for people whose rank in pre-Islamic Iran was that of marzbān; this is the definition found in al-Khwārazmì's treatise

17 Ibn Khallikān 1367/1948, 5:468.

18 Al-Muqaddasī 1906, 334-5; see Marlow 2016, 68.

19 Al-'Utbī 1424/2004, 434. In another instance, he calls the Sāmānids the mulūk al-sharq, "kings of the east", 184. For the use of the title malik by Sāmānid rulers, see Treadwell 2003. 20 Ibn Funduq Bayhaqī 1317/1938, 65.

21 Ibn Khurdādhbih 1889, 39.

22 Hiudūd al-'ālam 1962, and Paul 1994.

23 I have discussed terms for rural notables and local ruling houses in Paul 1994, 182-183; see also Paul 2016, 113-116.

24 Ibn Ḥawqal 1939, 347-348 and 354; Ibn Ḥawqal 1964, 341-2 and 347.

25 One example only: al-Ișțakhrī 1870, 112. 
on administrative terminology. It is also employed for the regional kings who ruled Iran whenever there was no empire. ${ }^{26}$ One of the most salient later narrative patterns is that of the central government sending out messengers to the mulūk al-atrāa f. ${ }^{27}$

Closest to al-Isțakhri in time and space is the hagiographic account of the life of Ibn Khafif Shīrāzì. It includes a report of a man of high descent who started out on the mystic's path, after which upper-class families-mulūk wa-ru'as $\bar{a}^{\prime}$ -of Shīrāz began offering him their daughters in marriage. The marriages took place, hundreds of them, but the man divorced the brides before consummation. Some of the girls were allowed to stay; one (a vizier's daughter) for over forty years. ${ }^{28}$ In another context, this same source uses mulūk together with salāțīn, saying that such people are in the habit of having soldiers run before them to drive the people out of the way as they ride through towns. The rider in question was 'Amr b. al-Layth the Șaffārid, and the setting Nīshāpūr. ${ }^{29}$

This term is thus not always correctly translated as "king" and not even as "ruler." ${ }^{30}$ Its meaning is broader since it includes figures and families who did not rule as royalty but were aristocrats, landholders, and very wealthy and influential persons, the top families of the upper class. Later, particularly in Seljuqid contexts, the term is mostly used for subordinate rulers who are members of the dynasty; as is well known, the term al-sulțān al-a'zam was reserved for the imperial overlord, al-sultān al-mu'azzam for whoever ruled over a significant part of the imperial territory, and malik for a ruler on the provincial level.

In the earlier periods, however, the term sometimes is paired with tunn $\bar{a}$, "landowners." Tunnāa' in turn comes alongside dahāqin or in other cases tujjār ("merchants", and particularly those in long-distance trade). Al-Ișțakhrī himself brings together mulūk and tunna $\bar{a}^{\prime}$ when he describes their apparel and other features. ${ }^{31} \mathrm{Al}$-Muqaddasī combines tunn $\bar{a}^{\prime}$ and tujjär in his description and praise of Samarqand. ${ }^{32}$ For Fārs, he mentions tunna $\bar{a}$ ' among the notables otherwise enumerated as mashāyikh and wujūh..$^{33}$ Ibn Ḥawqal has a very interesting passage

26 Al-Khwārazmī 1895, 114.

27 Al-Sam'ānī 1963, s.v. Bishkānī, 2:249, repeated in Yāqūt 1955, same lemma, 1:428.

28 Al-Daylamī 1955, 224.

29 Al-Daylamī 1955, 10.

30 Karev 2015, 300. Karev notes that the great landholder 'Ujayf b. 'Anbasa, a representative of the new supra-regional elite forming in Transoxiana after the conquest, is introduced as malik in a list of "kings" who came to submit to the caliph al-Mu'tașim.

31 Al-Ișțakhrī 1870, 138.

32 Al-Muqaddasī 1906, 278.

33 Al-Muqaddasī 1906, 430. 
about fashion styles of various upper-class groups in Fārs; the tunnā', he says, hold a middle course between the secretaries and the merchants tujjār. ${ }^{34}$ This is also their place in Māfarrūkhī's ranking of social strata. ${ }^{35}$

Morony describes a hierarchy within the upper class in the conquest period in Iraq. Beneath the royal family, he places the ahl al-buyūtāt, people descended from the noble houses of the Parthian period. ${ }^{36}$ This was presumably the group best matching the mulūk of later centuries. Morony continues: "At the bottom of this aristocratic hierarchy were the small landed proprietors (ar. tunna $\bar{a}$, syr. mare qorye)." ${ }^{37}$ Whereas Morony's study is based on western-Iraqi-material, de la Vaissière has studied the eastern centers of the emerging Muslim world. He describes the transition from Sogdian nobles to "the sons of Sogdian mulūk" and he insists on a ranking of nobility there. ${ }^{38}$ David Durand-Guédy gives some details about old Iṣfahānī families in his monograph on Iṣfahān in the Seljuq period. Quoting Ibn Hawqal, he observes that the dahāqin of pre-Islamic times were now the great tunn $\bar{a}$. Several families, he continues, were "directly connected to the Sasanian elite." 39

Returning to Fārs, al-Ișțakhrī and Ibn Hawqal stress the continuity between pre-Islamic and Islamic times. They list a number of noble families (ahl albuyūtāt, buyūt) who have held hereditary leading positions in the provincial administration for many generations; there is no doubt that these families were also large landholders. ${ }^{40}$ Some had such positions still in the mid-10 ${ }^{\text {th }}$ century, and had therefore transmitted their rank for no less than four centuries. But they are still considered separately from the mulūk: they occupy an elevated rank, but it is one level below the mulūk.

It would be interesting to follow the idea of precise social ranking within the upper class through the early Islamic centuries, but this is beyond the scope of this contribution..$^{41}$ It is however clear that the term mulūk is one of several used in marking social rank, and that invariably the mulūk occupy a place beneath the actual ruler, but above the rural gentry mostly known as the dahāqīn.

34 Ibn Ḥawqal 1939, 289; Ibn Ḥawqal 1964, 283.

35 Māfarrūkhī 1933, 87-8; English translation Durand-Guédy 2010, 28 -9.

36 Pourshariati 2011, 58-9.

37 Morony 1984, $186-7$.

38 de la Vaissière 2007, 33-6.

39 Durand-Guédy 2010, 29; Ibn Ḥawqal 1939, 367.

40 Al-Ișțakhrī 1870, 147-148; Ibn Ḥawqal 1939, 292; Ibn Ḥawqal 1964, 286.

41 See Marlow 2016, 113-126 as a starting point, and also Hayes 2015. 


\section{Mulūk in al-Ișțakhrī: Leading Families of Fārs}

In al-Iștakhrī’s text, ${ }^{42}$ various kinds of mulūk appear. He opens the passage stating that the province has produced many mulük and first mentions (but does not enumerate) the Persian kings of pre-Islamic times. Second comes the Sasanian general Hurmuzān; he is probably included because of his major role in the early Islamic community and because he was married to a woman from the family of 'Alī b. Abī Țālib. ${ }^{43}$ Then al-Isțakhrī names Salmān al-Fārisīi, ${ }^{44}$ to whom legend also ascribes noble birth (although not quite of the rank of a malik). All this history appears merely as an introduction, however. The main part of the passage is devoted to very real and very contemporary people. These families are of Arabic stock but have been living in Fārs since the early Islamic period; some of them could even have arrived on the northern shores of the sea in pre-Islamic times. It is beyond the scope of this contribution to go into details regarding all those families. After a brief introduction of the various mulūk families of Fārs, therefore, only one of them will be discussed at length.

The first family al-Iștakhrī presents are the Āl 'Umāra, whom he says are identical with or part of the Âl al-Julandā. The family was well connected on both sides of the sea, with its Fārsī center on the coast. The Fārs branch derived its wealth and influence mainly from control of the sea passages of the Persian littoral. Their main base was the fortress of Dikdān. ${ }^{45}$ This fortification, also known as Dākbāyāh, ${ }^{46}$ was renowned as one of the most impregnable in the world $;{ }^{47}$ it allowed its masters to take in the 'ushr of all the ships that passed by. Other branches of the $\bar{A} l$ al-Julandā were prominent on the Arab side in 'Umān, where they were for a while a ruling dynasty. ${ }^{48}$ Al-Iștakhrī links the Fārs branch to the story of Mūsā the Prophet on his quest for the Water of Life, and he tells us that the Qur'ānic verse "beyond them was a king who seized

42 Al-Iștakhrī 1870, $140 \mathrm{ff}$. The passage has been noted by previous authors, including Spuler 1952, 434. Spuler's focus is on the preservation of the Iranian pre-Islamic culture rather than the significance of these families in the political sphere.

43 See Shahbazi. He was indeed born into a family who had the rank which Morony describes for the early mulūk (Morony 1984). His province was Khūzistān (with al-Ahwāz as a center), so he is not immediately from the Fārs area, but some of his fights against the Arab invaders took place next to Iștakhr. See also Pourshariati 2011, 336-338.

44 On him, see Levi della Vida 2004; Levi della Vida notes that some versions see Salmān as coming from a dihqān background.

45 Pellat 2004.

46 Ibn Ḥawqal 1964, 268; Ibn Ḥawqal 1939, 272, also has qal'a Ibn 'Umāra.

47 Al-Mas'ū ūī 1962, I, 181 (§ 501).

48 Wilkinson 1975. 
every ship, unlawfully" refers to them. ${ }^{49}$ This detail implies they held the position in question since pre-Islamic times.

We thus see a family-or rather a cluster of families or clans-of Arab descent, long resident on the Fārs coast, deriving enormous incomes from 'taxing' the sea trade but still able to mobilize support from inland groups as well. We are not informed of what their landholdings consisted of, but it must be supposed they were large.

Another family, the Āl Abī Zuhayr al-Madīnī, is most interesting because one of their number, Abū Sāra, 'rebelled' in the times of the caliph al-Ma'mūn (r. $813-833$ ). His revolt is not dated more precisely, but it may well have been linked to the uprisings during al-Ma'mūn's prolonged stay in the East. Abū Sāra claimed authority for himself in Fārs. ${ }^{50}$ His rebellion had to be quelled by an army sent from Khurāsān and led by the Khurāsānī general Muhammad b. Ash'ath. ${ }^{51}$ An earlier representative of the family, Ja'far b. Abì Zuhayr, led a delegation of Fārsī rural lords-the mulūk Fārs-to Hārūn al-Rashīd (r. 786-809), who was extremely pleased and is quoted as having seen him as a potential vizier (unfortunately, he was prohibitively deaf). The Âl Abì Zuhayr controlled a strip of the coast like the $\bar{A} l$ al-Julandā and were also landholders; one of their members owned an entire district. This particular family apparently controlled a fuller set of resources than the $\bar{A} l$ al-Julandā, and they were well connected to the central government. ${ }^{52}$

The mulūk Fārs were thus a group of enormously wealthy families of Arab descent with two main sources of revenue: control of long-distance overseas trade and agriculture. Regarding the latter, we can assume these families actively owned vast stretches of land. They also farmed the taxes of many districts. In some cases, their economic importance translated into political influence; they were seen as representatives of their class at the caliphal court, and even some-

4918 (al-Kahf): 79, tr. Khalidi. Wa-kāna warā'ahum malikun ya'khudhu kulla safīnatin ghașban. "Ghașban" could also be translated by "violently".

50 Al-Ișțakhrī 1870, 141, yad'ū ilā nafsihi.

51 I have been unable to identify this person. He cannot be the Abū l-Sarāyā who revolted in southern Iraq (around Kūfa) in the beginning of al-Ma'mūn's caliphate (in 199 H/814 - 5 CE) because as far as I can see this revolt never spread to Fārs (al-Ṭabarī 1994, 8:528-535). This revolt was ended by Harthama b. A'yan. On the other hand, the Muhammad b. Ash'ath who is said to have quelled the revolt in Fārs cannot be the Muhammad b. Ash'ath al-Khuzā'ī who died during a summer raid into Anatolia in 149 H/766 CE (al-Ṭabarī 1994, 8:28). Did al-Ișțakhrī follow oral traditions here and mix up the names of both rebel and general? Other sources date Abu Sāra to the reign of al-Manșūr (al-Balādhurī 2000, 11:31), and this would fit the context better. 52 The information that 'Umāra and Zuhayr came to Fārs in the 'Abbāsid period therefore may well be mistaken, see Oberling/Hourcade. 
times rebelled against the central authorities. This seems to show that they also had some military power.

None of the local persons al-Iștakhrī enumerates in this passage can be found in the indexes of al-Tabarī and Ibn al-Athīr. The families likewise do not appear in the general historiography with its focus on the imperial center and its Arabocentric worldview. The man to whom the case study is devoted is an exception. In his case, the narrative in al-Iștakhrī can be confirmed in the universal chronicles; there is also some extra information in Ibn Ḥawqal, Ibn al-Balkhī, and Ibn Khallikān.

\section{Muḥammad b. Wāṣil and the Descendants of 'Urwa b. Udayya in Fārs}

My case study concerns Muhammad b. Wāșil b. Ibrāhīm. He came from a prominent family of Arab stock who moved to Fārs in the late $7^{\text {th }}$ century and settled around the provincial center of Isțakhr. The family grew very wealthy over time (it is unclear how) and it may be supposed many members of it held leading positions in the province. It is not possible to establish a genealogical tree. Only a few members emerge from the sources, and only a couple of episodes are told in sufficient detail to gain an idea of the family's social profile. It is clear, however, that they did not reside on the coast and were not as important in the overseas trade as other families; they were primarily landowners and tax farmers.

The family belonged to the Hanzala branch of the Banū Tamīm and Ibn Wāṣil therefore is introduced as al-Ḥanẓalī al-Tamīmī. The Banū Ḥanẓala were still present in the region in later days, but further west: Ibn al-Balkhī reports them living between Ahwāz and Bașra and from there down to the coast. In the time under discussion here, Muhammad b. Wāṣil's power and landholdings were centered in the region of Iștakhr. ${ }^{53}$

The first members of the family whom we can trace in the sources were Khārijīs, opponents of both 'Alī b. Abī Tâalib (r. 656-661) and the Umayyad caliph Mu'āwiya (r. 661-680) whose governor in southern Iraq, Ziyād b. Abīhi, killed many out of their numbers. These included the ancestors of Muhammad $b$. Wāṣil, 'Urwa b. Udayya and his brother Abū Bilāl Mirdās b. Udayya; Abū Bilāl Mirdās, a prominent man among the Khārijīs, was killed in $61 \mathrm{H} / 680-681$

53 Ibn al-Balkhī 1921, 69. 
CE. ${ }^{54}$ In the sources, Abū Bilāl is shown as a model of ascetic piety, a quietist for most of his life until his final 'rebellion' (khurūj). This khurūj (literally "leaving” or "going out") drove him from Bașra. He went to Ahwāz with a small group of followers, won an unexpected victory over an Umayyad detachment, and finally was defeated and killed next to Dārābjird, in Fārs. ${ }^{55}$ His brother 'Urwa does not seem to have participated in Abū Bilāl's khurūj, but he was still executed in Bașra later.

Al-Ma'mūn appointed 'Umar b. Ibrāhīm, one of this family, as leader of the maritime ghazw in the Persian Gulf. The target of this expedition was a group called the Qatariya-the real or presumed successors of a central figure in early extreme Khārijism called Qațarī b. al-Fujā'a, active in the last decades of the $7^{\text {th }}$ century. ${ }^{56}$ Ibn A'tham al-Kūfĩ details the battles against Qațarī, who whilst fleeing the caliphal troops followed the same route as Abū Bilāl Mirdās via Ahwāz to Dārābjird..$^{57}$ Ibn Hawqal links the Qațarīya to the Șufrīya, another extremist group of Khārijites, saying that 'Abādān (next to the mouth of the Tigris on the Persian Gulf coast) "is a stronghold where warriors live who fight the Șufrīya and the Qațarīya and other pirates." 58

The family thus either dropped their Khārijī sympathies in the early $9^{\text {th }}$ century or followed a quietist form of Khārijism as their ancestors had done. The campaign is presented very much as a family enterprise: it was equipped (and apparently at least partly paid for) by another family member, Abū Bilāl Mirdās b. 'Umar, son of that 'Umar b. Ibrāhīm who led the enterprise. As this Mirdās was called by his kunya Abū Bilāl, the name Abū Bilāl Mirdās resurfaced; a reminder that in such genealogically conscious families, names were passed on.

The family was extremely wealthy, evident in the fact that it could muster the funds for such a campaign. Abū Bilāl Mirdās b. 'Umar was charged a kharāj or annual land tax of roughly three million dirham. His relative Muham-

54 He even has an entry in the $E I^{2}$ : Levi della Vida 1993. Levi della Vida completes the genealogy in pre-Islamic times: the Arab tribal group was Rabī'a b. Ḥanẓala b. Mālik b. Zayd Manāt, also called Rabī'a al-wusțā. Mirdās was descended from Ḥudayr b. 'Amr b. 'Abd b. Ka'b; Udayya was the name of his mother or grandmother. He was mostly known by his kunya Abū Bilāl. 55 Hagemann 2016, 41-42. The narrative of this khurūj also appears in Levi della Vida 1993. For the figure of Abū Bilāl, see also Gaiser 2014. Both Hagemann and Gaiser do not aim at reconstructing the events, but concentrate on the narrative itself.

56 Van Ess 1992, 573, 613.

57 Al-Kūfī 1392/1972, 1-41. No Ḥanẓala appear in this narrative.

58 Ibn Ḥawqal 1939, 48: kāna fīhi al-muhāribūn li-l-Ṣufrīya wa-l-Qațarīya wa-ghayrihim min mutalașșișa al-bahrr. Van Ess 1992 does not list a group called the Qațarìya but has much information on the Șufrìya. 
mad b. Wāṣil had to pay about the same sum..$^{59}$ In total the family's members owed a sum of 10 million dirham to the state. (To put this in perspective, the entire province was good for about 30 million dirham. ${ }^{60}$ ) The sum probably means that the family was engaged in tax farming, so that the amount stated was not due merely from their own landholdings but was the sum total they had to deliver to the caliphal administration. On the other hand, al-Iștakhrī explicitly says they owned many villages. For their administration, they may have employed Iranian experts, at least in earlier periods; we hear of a man of dihqān extraction who managed Hanzalī holdings in Fārs and was himself a client of the Hanzala. ${ }^{61}$

Another asset which made the Hanzali family influential was their control of castles. Castles were a necessary feature of local lordship. As mentioned above, the Āl al-Julandā held the castle of Dikdān on the coast. Muhammad b. Wāṣil acquired at least one castle in the region of Ișțakhr, next to Rāmjird, called Sa īidābād. This was an old fortress, as Ibn Hawqal tells us. It had been in use in Sasanian times and in the early Islamic period it had served as a stronghold for the governor Ziyād b. Abīhi (who killed so many Khārijites, among them the two ancestors of Muhammad b. Wāṣil). Muhammad b. Wāṣil ordered it demolish-

59 Al-Ișțakhrī 1870, 142.

60 Ibn Khurdādhbih 1889, 48, who adds that in pre-Islamic times the state took 40 million from the province. For the year 350 H/961 CE, Ibn Hawqal 1964, 299 and Ibn Hawqal 1939, 304 gives 1.5 million dinar (the exchange rate between silver dirham and gold dinar is a matter of dispute; the figures presented here would make a rate of 20 dirham to the dinar probable). Ibn Hawqal's figures may point to an organized financial bureaucracy; these were the times of 'Adud al-Dawla the Būyid (338-372 H/949-983 CE). Compare this to the 15 million dirham which Ya'qūb b. alLayth (in $255 \mathrm{H} / 869 \mathrm{CE}$ ) reportedly offered to get the caliphal administration from the taxes of Fārs if he were appointed over the province; Ibn Khallikān 1367/1948, 5:447. When Ya'qūb came to Fārs again in or around $260 \mathrm{H} / 873-4 \mathrm{CE}$ and was able to administer the taxes in a regular way, he got the 30 million that seem to have been the norm in this period. He had his representative in Fārs, Muḥammad b. Wāșil, send only five million on to the caliphal administration (Ibn Khallikān 1367/1948, 5:453). The same source mentions that the Șaffār had an appointment for a number of provinces (including Khurāsān, but also Fārs) on condition that he deliver twothirds of the taxes he collected. In that case, the caliphal court would have expected around 20 million dirham from Fārs. Ibn Khallikān 1367/1948, 5:462. For more figures relating to the taxes due from Fārs, see Spuler 1952, 468-469.

61 Al-Khațīb al-Baghdādī 1931, 6:175, no. 3231. One member of the family of the singer Ibrāhīm b. Māhān is quoted as saying kānat fì aydīna diyā' li-ba'ḍ al-Hanzaliyīn. There is a problem here, however. Ibn al-Nadīm puts it differently. He has the family come from Arrajān (in western Fārs, where Muhammad b. Wāșil's family is not attested), and says they fled from there in the Umayyad period because of unjust tax collectors. Ibn al-Nadim also has them as clients of the Ḥanẓala, mawāliyunā [min] al-Ḥanzaliȳin, wa-kānat lahum dịȳ'cindanā, which does not necessarily mean that the Iranian family managed these estates. Ibn al-Nadim n.d., 157. 
ed, only to later have it rebuilt. ${ }^{62}$ He then kept his treasure there-we learn that because it was carried off when Ya'qūb b. al-Layth the Șaffār conquered the castle. The place was later used as prison.

It is not stated which castle or castles the family had before Muhammad b. Wāṣil took over Sa īdābād, but we can suppose that all branches of the Hanẓala in Fārs had such strongholds. Al-Ișțakhrī speaks of 5,000 castles in Fārs, a figure Ibn Hawqal repeats; this figure refers to the fortresses in the mountains and similar places that were close to settlements but not an integral part of them. Citadels and urban fortifications come on top of that. ${ }^{63}$ It is interesting to note that Ibn Hawqal quotes a man of the tunna $\bar{a}$ ' group as his source: evidently that is who was knowledgeable in such matters-probably because they owned such places themselves.

There can be no doubt that the Hanzali family was one of the pillars of 'Abbāsid power in Fārs, together with the other noble houses of the mulūk and the ahl al-buyūtāt.

\section{Muḥammad b. Wāṣil's 'Rebellion'}

In the mid- $9^{\text {th }}$ century, the caliphal administration weakened and troops of military slaves dominated the new capital of Sāmarrā'. The most striking single event, remembered because it ushered in a long period of 'anarchy' in Sāmarrā', was the assassination of al-Mutawakkil in $247 \mathrm{H} / 861 \mathrm{CE}{ }^{64}$

For some time, the caliphs had been ruling large parts of Iran including Fārs through a hereditary line of super-governors, the Țāhirids. From the perspective of Fārs, the Tāhirids were overlords, but also always-at least formally-agents of the caliphal central administration. In this time of instability in Fārs, the main actors were representatives of the Țāhirids and Ya'qūb b. al-Layth the Șaffār as external powers on the one hand, and regional figures on the other.

What was at stake was evidently the tax revenue from Fārs, money of increasing importance for Sāmarrā': Iraq had become problematic to tax, and not much could be expected from Khurāsān any longer. To give an example: in Muharram $256 \mathrm{H} /$ early December 9, $869 \mathrm{CE}$, ten million dirham and a half

62 Ibn Ḥawqal 1964, 268, Ibn Ḥawqal 1939, 272-273.

63 Ibn Ḥawqal 1964, 268, Ibn Ḥawqal 1939, 272. Ibn al-Balkhī mentions more than 70 castles conquered and then destroyed by the Seljuqid governor Chawlī, and he specifically enumerates only those which were not in this number. Therefore, it is not completely surprising that Sa 'īdābād is not mentioned. Ibn al-Balkhī 1921, 158.

64 Kennedy 2016, 147. 
in tax payments arrived in Sāmarrā' from Fārs. ${ }^{65}$ This money allowed a clique of military slaves to pursue an action against al-Muhtadī (r. 869-70) that they had been forced to postpone for lack of funds. Some kind of tax administration was still at work in the province.

Until 255 H/869 CE, a man called 'Alī b. al-Ḥusayn b. Quraysh intermittently controlled Fārs. ${ }^{66}$ At some times he had a caliphal appointment and at others he rebelled against the official representative of Tāhirid and caliphal power. The exact details of the struggle in the 250s H/860s CE between the Tāhirids, the Șaffār (the rising power in the east), and local actors like 'Alī b. al-Ḥusayn need not detain us here. According to al-Tabarī (at the beginning of the story of Muhammad b. Wāṣil), the Tāahirid representative in Fārs was Ḥārith b. Sīmā. Muhammad b. Wāṣil and a Kurdish emir called Aḥmad b. al-Layth rose against Ḥārith b. Sīmā and killed him in 256 H/870 CE. ${ }^{67}$

\section{Muḥammad b. Wāṣil in Power}

Muhammad b. Wāṣil controlled Fārs from 256-261 H/870 - 875 CE. But he always accepted an overlord's authority, either that of the caliph or Ya'qūb b. al-Layth or both. Ibn Khallikān calls him the governor of Fārs, in charge of finances and war at the same time; this may go back to an agreement between the caliph and Ya'qūb. Al-Ṭabarī also says Ibn Wāșil submitted to the Șaffār; when Ya'qūb insisted that he hand over the province to a representative of the caliph, this was done in $258 \mathrm{H} / 872 \mathrm{CE}^{68}$

The Tārīkh-i Sīstān has Ya'qūb come to Kirmān at the beginning of al-Mu'tamid's caliphate (r. 256-279 H/870 - 892 CE). Muhammad b. Wāṣil met him with his army and offered submission and obedience together with presents and much wealth. ${ }^{69}$ This presupposes that Ibn Wāṣil had been in control of Fārs for some time, so the event should probably be dated to $257 \mathrm{H} / 870-871 \mathrm{CE}$. In return, the source continues, Ya'qūb gave him Fārs. Ibn Wāṣil also sent some

65 Ibn al-Athīr 1965, 7:221.

66 Ibn Khallikān 1367/1948, 5:447-450.

67 Al-Ṭabarī 1994, 9:474 (III:1839 in de Goeje’s edition); Ibn al-Athīr 1965, 7:240.

68 Al-Ṭabarī 1994, 9:490 (III: 1859); Ibn al-Athīr 1965, 7:257.

69 Tārīkh-i Sīstān 1314/1935 216; Istoriia Sistana 1974, 216, with note 638 which repeats Smirnova's note 543 . 
tax monies to the caliphal court at that time. ${ }^{70}$ He had his own tax agents (bun$d \bar{a} r)$ : these men were later remembered as having worked for him. ${ }^{71}$

In $258 \mathrm{H} / 871-872 \mathrm{CE}$, Ibn Wāṣil returned to the caliphal ță $a$ (obedience); that is, he formally submitted to the caliph-he had been obedient before, but then rebelled. At the same time, he accepted a new caliphal agent, Muhammad b. al-Husayn b. al-Fayyāḍ, as responsible for the finances (al-kharāj wa-l-diyā') of Fārs. $^{72}$ This agent is not mentioned again. There is no information regarding what his appointment meant for the holder of the corresponding military position (al-harb): in some cases, one man held both positions, but they also sometimes devolved onto two appointees.

Some years later, in 261 H/874-875 CE, Ibn Wāșil defeated a caliphal force sent against him. The commander of this caliphal force was 'Abd al-Rahmān b. Muflih and his second-in-command was Ṭāshtimur. In the battle, Ṭāshtimur was killed and 'Abd al-Raḥmān taken prisoner. Ibn Wāṣil refused to negotiate his liberation, and Ibn Muflị died in captivity. ${ }^{73}$ Muhammad b. Wāṣil now was master of the province again, and he expanded into neighboring provinces such as Khūzistān. It was from there that he hastened east to meet Ya'qūb b. al-Layth, only to be defeated at al-Bayḍā' (see below).

At some point, Ibn Wāṣil had the ruined fortress of Sa 'īdābād (Rāmjird, district Iștakhr) repaired, and tried to put down local resistance by conquering other fortresses held by recalcitrant local lords. But he had trouble taking some of them: Al-Iștakhri (and Ibn Hawqal following him) specifically name the fortress of Kāriyān in the Tīn mountains-he could not break the resistance of the castellan there, Aḥmad b. al-Ḥasan al-Azdī. ${ }^{74}$

In general, however, Muhammad b. Wāṣil seemed well established. His relationship with the caliph was troubled, but he must have been followed by a majority of the local lords and castellans. He had his own agents, including taxation specialists, working for him. He delivered some of the taxes produced to the caliphal court, if irregularly. The caliph could not remove him-an attempt to do so

70 Ibn Khallikān 1367/1948, 5:453. The sum quoted is five million dirham; Ya'qūb had taken the (usual) thirty million at the same time. See above, note 60.

71 In their list of old families who produced able administrators, al-Iștakhrī and Ibn H̦awqal quote the Marzbān b. Zādbih family (judging by the name, of dihqān stock). Al-Ḥasan b. Marzbān worked as bundār for Muḥammad b. Wāṣil and later for Ya'qūb b. al-Layth; Ibn Ḥawqal 1964, 286; Ibn Ḥawqal 1939, 292; al-Ișțakhrī 1870, 147.

72 Al-Ṭabarī 1994, 9:490 (III:1859); Ibn al-Athīr 1965, 7:257.

73 Al-Ṭabarī 1994, 9:513; Ibn al-Athīr 1965, 7:275. Both commanders participated in earlier campaigns against the Zanj.

74 Al-Ișțakhrī 1870, 116; Ibn Ḥawqal 1964, 269/Ibn Ḥawqal 1939, 272. It is not stated whether old grudges between Azd and Tamīm played a role here. 
had failed, and most of the caliphal military and financial resources were now directed against the Zanj who were clearly the more dangerous threat. ${ }^{75}$ The geographer al-Ișțakhrī, a regional source, calls Ibn Wāṣil "governor” of Fārs (wālī), and probably he reflects local feelings. ${ }^{76}$ And as we have seen, all the other sources see Ibn Wāṣil as the legitimate governor of Fārs as well, at least up to a point.

\section{Reasons for 'Rebellion'}

In order to understand the reasons for this movement, we turn to a story told only in al-Iștakhrī. A group of Turkish military slaves, reportedly forty officers, were given land grants (iqța $)$ in Fārs, or at any rate they went there and claimed they had. Their commander-in-chief, whom al-Ișțakhrī calls al-Muwallad and who therefore was probably the noted slave general Muhammad b. al-Muwallad, ${ }^{77}$ tried to prevent abuse, and therefore his subordinates rebelled against him. He sought refuge with Mirdās b. 'Umar, Muhammad b. Wāṣil's paternal cousin. Abū Bilāl Mirdās gave shelter and asylum to al-Muwallad and saw to it that he made his way back to Baghdad. With al-Muwallad gone, the Turkish officers elected another leader-Ibrāhīm b. Sīmā, apparently the brother of that Ḥārith b. Sīmā whom Ibn Wāṣil is reported to have killed. ${ }^{78}$

The caliphal administration now asked Mirdās to pursue and to punish the Turks, whom they wanted killed; however, Mirdās excused himself. The caliph then addressed the same request to Muhammad b. Wāṣil, and Ibn Wāṣil indeed took action by executing almost all forty Turkish officers. Only Ibrāhīm b. Sīmā

75 Their revolt lasted from 255-270 H/869-883 CE. Popovic 2002.

76 Al-Ișțakhrī 1870, 116; Ibn Ḥawqal 1964, 269; Ibn Ḥawqal 1939, 273: kāna Muḥammad b. Wāṣil al-Hanzalī wālī Fārs yalīhā ḥarban wa-kharājan; note the explicit mention of both financial and military matters.

77 Al-Ișțakhrī 1870, 142. This man led military action against the Zanj in Bașra in late 257 H/871 CE. In Rabīi I, 259 H/January 873 CE, he was appointed to lead the war against the Zanj in the region of Wāsiț. In 261 H/874- $875 \mathrm{CE}$, when Ya'qūb defeated Muḥammad b. Wāṣil, he was not in the Fārs region either. In later years, e. g. in 264 H/877-878 CE, he was still busy fighting the Zanj as military commander of Wāsiț. Thus his presence in Fārs is not documented for the relevant years in al-Ṭabarī. Later, he defected to the Șaffārid army.

78 Ibrāhīm b. Sīmā is also a known commander. In 257 H/871 CE, he fought the Zanj west of Ahwāz, and al-Ṭabarī explains that he "retreated from Fārs where he had been together with al-Haārith b. Sīmā in the field/steppe known as the Arbuk steppe, this is between al-Ahwāz and the bridge" (al-Ṭabarī 1994, 9:479). In the following years, Ibrāhīm was also involved in the wars against the Zanj. He was killed in the battle of Dayr 'Āqūl (otherwise a victory for the caliphal troops) in Rajab 262 H/April 876 CE. 
and a handful more escaped. Subsequently Muhammad b. Wāṣil took over in Fārs.

If we consider that the report of the killing of Hārith b. Sīmā is not in alIșțakhrī and the story of the killing of the Turkish officers is not in al-Tabarī, we may ask whether both stories could refer to the same chain of events. AlTabarī shows Ibrāhīm b. Sīma, who escaped the massacre, as coming to Ahwāz "retreating from Fārs where he had been with al-Hāarith b. Sīmā" in 257 $\mathrm{H} / 871 \mathrm{CE}^{79}$ If the killing had taken place just a bit earlier, it can be dated to 256 H/870 CE, the year al-Ṭabarī reports the killing of al-Ḥārith and Ibn Wāṣil's usurpation of Fārs. This date also works well with reports in other sources. AlIștakhrī's report is biased: the killing took place on caliphal orders, so it cannot be laid at Ibn Wāșil's door.

The sources do not give any reason for Ibn Wāșil's action; they put it into the general basket of insubordination and rebellion. Clues can be obtained (with caution) from the timing of the uprising. Al-Iștakhrī explicitly links the killing of the military slaves in Fārs to two factors: firstly, the breakdown of central authority, and secondly, the greed ("injustice") of the Turks who held iqțā 'ât. When they came to Fārs they apparently tried to seize both money and goods. This encroached on the traditional rights of the established upper rung of the landed elites in several ways. They were no longer the direct partner of the central administration. They could no longer make a profit themselves out of tax farming. They probably had to disburse taxes and tax arrears in unprecedented amounts. And they had to confront a group of people who were quite prepared to use violence to get what they wanted. Taken together, these reasons were enough to make the provincial nobility think of rebellion and therefore it is unlikely that Muhammad b. Wāșil acted only for his own sake.

\section{The End}

The end came quickly. Again according to al-Ișțakhrī, ${ }^{80}$ Ya'qūb the Șaffār was called in-not by the caliph, but by Mirdās, Ibn Wāṣil's cousin, who feared for his life if Ibn Wāṣil were to continue. Ya qūu invaded Fārs in Shawwāl 261 H/ July $875 \mathrm{CE}$, and in the ensuing battle near Bayḍā' in the region of Ișțakhr Ibn

79 Al- Țabarī 1994, 9:479-480. There is no explanation of why and fearing whom Ibrāhīm should have "retreated" from Fārs.

80 According to the Tārīkh-i Sīstān, an erstwhile Șaffārid commander, Muhammad b. Zaydawayh, enticed Muhammad b. Wāșil to rise against Ya'qūb. Tārīkh-i Sīstān 1314/1935, 226; Istoriia Sistana 224. 
Wāṣil was defeated. Ya'qūb also took his fortress or fortresses. The booty was enormous-40 million dirham ${ }^{81}$-and according to al-Ṭabarī Ya'qūb took Ibn Wāșil's maternal uncle Mirdās prisoner. ${ }^{82}$ There is a difficulty here: al-Ișțakhrī sees Mirdās as Ibn Wāṣil's paternal cousin, and in an entirely different role. Ibn alAthīr adds to the confusion over this man, whom he sees as conducting negotiations between Ya'qūb and Ibn Wāșil. ${ }^{83}$ In his version, when Ya'qūb entered Fārs, Ibn Wāṣil was in the region of Ahwāz west of his home country. He sent his maternal uncle (khāl) Abū Bilāl Mirdās to negotiate with Ya'qūb, and as a result Abū Bilāl tendered Ibn Wāșil's submission. This was not what Ibn Wāṣil had intended, and when Abū Bilāl came back he had him imprisoned together with Ya'qūb’s emissaries. Battle thus became inevitable. Ibn Wāșil had lost many men, foot soldiers as well as cavalry, from hunger and thirst. Just as the fighting started, Ya'qūb said to Abū Bilāl (whom the account does not previously mention as freed): “Ibn Wāṣil has betrayed us.” Ibn Wāṣil's men then fled without doing battle. ${ }^{84}$

Besides these accounts of the war and battle between Ya'qūb and Ibn Wāṣil, there is the material found in the Tārīkh-i Sīstān. The Tārīkh-i Sīstān underlines Ya'qūb's resourcefulness; Ya'qūb wins because he outwits Ibn Wāșil. ${ }^{85}$ Its end sees Muhammad b. Wāṣil locked up in a fortress and Ya'qūb proceeding to Ahwāz accompanied by Abū $M u^{\prime}$ ādh Bilāl b. al-Azhar. ${ }^{86}$ One would like to know whether there is any link between this Bilāl and Abū Bilāl Mirdās, but that cannot be established and would seem unlikely at first glance because of the nasab of $\mathrm{Abu \overline { } \mathrm { Mu }} \mathrm{M}^{\mathrm{a}} \mathrm{dh} .{ }^{87}$

81 In comparison, Ya'qūb is said to have left at his death the fantastic sum of four million dinar (in gold, 'ayn) and fifty million dirham (silver, waraq), not counting equipment and so forth. Ibn Khallikān 1367/1948, 5:462. The rendition of the fortress is also related in the Tärikkh-i Sīstān, and there is a much embellished story regarding how Muḥammad b. Wāșil finally unveiled the secret of how to get into it. Tārīkh-i Sistān 1314/1935, 229-230; Istoriia Sistana 1974, 226 - 227.

82 Al-Ṭabarī 1994, 9:514 (III:1888).

83 This dilemma has been noted by Bosworth already, and I am unable to offer a solution. Bosworth 1994, 151.

84 Ibn al-Athīr 1965, 7:276-277.

85 The prototypical 'ayyār, Ya'qūb is often shown outwitting his enemies; see Tor 2007. It is therefore no wonder that later authors relate further stories about Ya'qūb duping Muhammad b. Wāșil. One of those is in al-'Awfī 1393/2015, 195-196. In the subsequent anecdote (196198), the lord of Dīnawar in his turn bests Muhammad b. Wāṣil. In the India of the $13^{\text {th }}$ century, Muhammad b. Wāṣil was still remembered as a bit dumb and no match for the Șaffār (or even for ordinary local lords). My thanks to Peter Verkinderen for the reference to al-'Awfī.

86 Tārīkh-i Sīstān 1314/1935, 226-230, Istoriia Sistana 1974, 223-227.

87 This man's career can be followed to some extent in the Tārīkh-i Sīstān. (He is, however, unknown to the central chronicles.) He ruled Fārs on behalf of 'Amr b. al-Layth in 274 H/887 CE 
After the battle at Bayḍā', Ibn Wāṣil's troops dispersed. According to alTabarī, Ibn Wāṣil escaped into the mountains. After a short while, the political wind changed again. In the question which continued to occupy policy makers at the caliphal court, namely whom to appoint over the eastern provinces, the Șaffār or one of the Țāhirids, the pendulum swung again-this time in favour of the Tāhirids. Ya'qūb had been beaten at Dayr 'Āqūl on Rajab 9, 262 H (April $8,876 \mathrm{CE}),{ }^{88}$ and though the defeat was not a catastrophic one it did much to harm Ya'qūb's reputation as a military leader. Ya'qūb was once more publicly cursed, and the caliph appointed Ibn Wāșil to rule Fārs. ${ }^{89}$ But according to the same source, in that year Ya'qūb regained control of Fārs and Ibn Wāșil fled. The following year, in 263 H/876 - 877 CE, one of Ya'qūb's commanders succeeded in taking him prisoner. ${ }^{90}$ Perhaps al-Ișțakhrì's report about Ibn Wāṣil's imprisonment should be related to this second occasion: Ibn Wāṣil was taken prisoner either immediately after the battle at Bayḍā' or shortly after. He was brought to Sīrāf and later handed over to Ya'qūb who transferred him to Thamm, another fortress. Ibn Wāṣil spent two years in this fortress. For a short while, when Ya'qūb was in Jundayshāpūr, Ibn Wāṣil was able to get free and take over the fortification; but Ya'qūb soon sent orders to kill him. ${ }^{91}$ No source gives a death date for Ibn Wāṣil.

\section{Later History}

The end of Muhammad b. Wāṣil did not mean that his family had lost all influence. When the Būyid 'Alī b. Būya ('Imād al-Dawla) conquered Shīrāz in $322 \mathrm{H}$ / $934 \mathrm{CE}$, the resulting taxes (or tax arrears) were farmed out. Three local land-

(Tārīkh-i Sistān 1314/1935, 247, Istoriia Sistana 1974, 239); he is said to have accomplished his task there well. He continued in Fārs but was employed also on campaigns elsewhere. At the end, perhaps in 291 H/904 CE, he was ordered to go into exile in Sīstān; he gathered "his belongings, his people, and set in march his slaves and his warriors and everyone who was beholden to him and had them depart for Sīstān" (māl wa-ahl-i khwīsh bar girift wa-ghulāmān wa-sipāh-i khwīsh harchi khāṣṣ-i ū būd wa-rāh-i Sīstān bar girift), Tārīkh-i Sīstān 1314/1935, 275, Istoriia Sistana 1974, 263. But he was intercepted by Ṣaffārid forces and imprisoned in Muhammad b. Wāṣil's fortress. If by any chance he was a member of the Hanzalì clan, this would be ironic indeed. It seems clear that he was a Fārsī nobleman, and even if he was not Abū Bilāl Mirdās' son, he might still belong to the larger family.

88 Bosworth, "Dayral-"Āqūl."

89 Al-Ṭabarī 1994, 9:519.

90 Al-Ṭabarī 1994, 9:530.

91 Al-Ișțakhrī 1870, 143-144. 
holders are named explicitly among those who took the contracts, among them an Ibn Mirdās. There can be no doubt that this is a member of the Hanzali family. ${ }^{92}$

Ibn al-Balkhī speaks of a family of qāọīs in Fārs who were admired for both their knowledge in legal affairs and for their long-lasting influence. The first man whom he mentions is Abū Muhammad 'Abdallāh b. Aḥmad b. Sulaymān b. Abī Burda al-Fazārī, dated to the times of the caliph al-Rādī (r. 322-329 H/934-940 CE). ${ }^{93}$ Abū Muhammad's descendants spread into Kirmān and Fārs, acquiring positions and landed property as far afield as Ghazna. At some point, his son Abū Nașr (who apparently stayed in Fārs) got married to a girl from the Mirdāsiyān $\mathrm{ra}^{\prime}$ ìs (this word probably meaning wealthy landowners, well connected, with a potential for high positions in the provincial administration; as mentioned above, $r a^{\prime}$ 's is a term which continues an association with malik in some contexts). ${ }^{94}$

As a consequence, their son 'Abdallāh held both positions: he was qāọī as a legacy from his father and he inherited the riyāsa from his mother's family. ${ }^{95}$ It cannot be shown definitely that the Mirdāsiyān in Ibn al-Balkhī are the descendants of Abū Bilāl Mirdās-whether the early Khārijite or the later malik-but it is highly probable. Mirdās is not a frequent name and there is no other candidate for an eponym of any Mirdāsiyān as a ra'īs family in Fārs. The descendants of this 'Abdallāh were in turn highly respected in their offices, both the qad a $\bar{a}^{\prime}$ and the riyāsa, and Ibn al-Balkhī proudly informs his readers that his grandfather had the privilege of working with one of them in the beginning of the Jalālī era (the reign of the Seljuqid sultan Malikshāh, 1072-1092). ${ }^{96}$ This would give the Fazārī/Mirdāsī family of qā dịs and ru'asā' an active timespan of over a century. If we include this period, the Hanẓalī mulūk of Fārs have a historical record of four centuries and a half, ranging from 'Alī b. Abī Ṭālib in the mid $-7^{\text {th }}$ century to the reign of Malikshāh in the late $11^{\text {th }}$.

92 Ibn Miskawayh 1916, 300. The other two were al-Nawbandajānī and a member of the Fasānjus clan.

93 I have been unable to identify this person.

94 This kunya is the only part of the name Ibn al-Balkhĩ quotes, and therefore it is impossible to find out more about him.

95 Ibn al-Balkhī 1921, 117-118. Pas qaḍā'-i Fārs ba-mīrāth-i pidar wa riyāsat-i ān wilāyat ba-mīrāth-i khānadān-i mādar badū rasīd.

96 Ibn al-Balkhī 1921, 118. It is known that Ibn al-Balkhī’s grandfather was a mustawfì under various rulers in the late $11^{\text {th }}$ century; see Bosworth, "Ebn al-Balki.." 


\section{Muḥammad b. Wāṣil as One of the Mulūk Fārs}

We have seen that al-Iștakhrī's mulūk Färs were the top level of the provincial landholding elite, enormously wealthy, politically influential, and eligible for high offices. The Hanẓalī family to whom Muhammad b. Wāṣil belonged was one of several, but it seems that Ibn Wāșil himself was an exceptional figure.

Even if the narratives in the various sources seem to defy attempts at reconstructing the chain of events, some points are clear on the level of social history. First, it is clear where Muhammad b. Wāṣil got his financial resources. His entire family had huge landholdings and they were possibly also involved in tax farming, although there is no clear indication of the latter in the sources. His military resources included control over at least one castle (which he had repaired while he was in power), and probably other places too.

But military resources also mean military manpower. Here the sources are less forthcoming. In his action against the Turks from Sāmarrā' whom he had killed on caliphal orders (as al-Ișțakhrī claims), he relied on his personal retainers, a group of people whom al-Ișțakhrī introduces as hāshiyatuhu wa-ahl ță ${ }^{\text {atihi }}{ }^{97}$ It is interesting to see that a figure like Muhammad b. Wāșil had men in his $t \bar{a}^{\prime} a$, his obedience, a term normally used to indicate those serving and obeying rulers. The hāshiya may have been something like household troops, people personally dependent on Muhammad b. Wāṣil as their lord, whereas the ahl țā'atihi could correspond to a larger group of supporters and people who followed him for the time being. In the Tärīkh-i Sìstān, it is taken for granted that Ibn Wāșil had his own troops, though we do not learn who they were. In Ibn al-Athī's report on the events leading to the battle at alBayḍā' between Ibn Wāṣil and Ya'qūb the Șaffār, infantry and cavalry troops are mentioned in Ibn Wāșil's army; this might point to an ancient type of mobilization with a comparatively high proportion of drafted followers of local lords fighting on foot.

Muhammad b. Wāṣil is also reported to have mustered Bedouin troops in Fārs, from Tamìm (the source mentions they were from his tribal group), and from 'Abd Qays in Bahrayn. Both groups had sent ill-equipped and ragged men. ${ }^{98}$ Since this information comes from a contemporary source, two points are interesting: first, it is taken for granted that Muhammad b. Wāṣil has a military following, and second, his rule extends as far as Bahrayn.

97 Al-Iștakhrī 1870, 142. See also the description of Bilāl b. al-Azhar’s following when he left Fārs for Sīstān, above, note 88.

98 Ibn al-Mu'tazz 1939, 407. I owe this reference to Peter Verkinderen. 
Another important asset were allies, political resources that could be turned into military ones in case of need. Groups the sources identify as Kurds appear as allies of Muhammad b. Wāṣil (and of other local lords as well). One of the relevant Kurdish lords was Ahmad b. al-Layth (no relation of the Șaffārids, of course). Whereas Ibn Khallikān shows this man as Ya'qūb's most important enemy and as an ally of 'Alī b. al-Husayn b. Quraysh in the conquest of Fārs, ${ }^{99}$ he appears as Muhammad b. Wāṣil's accomplice in the uprising against Ḥārith b. Sīmā in al-Ṭabarī. ${ }^{100}$ Apparently in both cases Kurdish fighters were seen as a necessary but problematic factor in military action in Fārs; they were always pillaging and raping, and their loyalties were shaky. Still, Muhammad b. Wāșil must have made use of Kurdish forces repeatedly since after his defeat Ya'qūb cracked down on a Kurdish group, the men of Mūsā b. Mihrān, for sympathizing with Ibn Wāṣil. Probably some out of their numbers had participated in Ibn Wāṣil's campaigns. ${ }^{101}$

Apart from the Kurdish lords, what about the Iranian or Arab local lords, including the families of the mulūk Fārs? Here, we have no information besides the anecdote that one of them refused to join Muhammad b. Wāșil who therefore laid siege to his castle-without, however, managing to take it. It is tempting to conjecture that many others did in fact join Ibn Wāșil, but this is clearly stated nowhere.

After his initial successes, Ibn Wāṣil may have pursued the goal he achieved at the end: to be appointed as governor of Fārs. It seems that he also was Ya'qūb's man in that province; at any rate, he was prepared to serve the Șaffār as well as the caliph. The Taanhirids were no longer part of the game in any practical way as far as Fārs was concerned. Ibn Wāṣil was one of those who aspired to positions of leadership in their own province. The sources are silent about who he may have had in mind as a role model (if anyone), but perhaps it is no coincidence that al-Ișțakhrī makes some comments about the Sāmānids immediately after his passage on Ibn Wāṣil, and that the Sāmānids appear as mulūk al-Furs. ${ }^{102}$

99 Ibn Khallikān 1367/1948, 5:448 - 450. Ahmad's Kurds were made responsible for a number of outrageous deeds, among them the raping of hundreds of noble girls. See also Tor 2007, 129. 100 Al-Ṭabarī 1994, 9:474, year 256 (III:1839); Ibn al-Athīr 1965, 7:240.

101 Al-Ṭabarī 1994, 9:514, year 261. Al-Ișțakhrī presents Mūsā b. Mihrāb (not Mihrān) as leader of the Bādhinjān ramm of Kurds in Fārs, the most warlike group because of the horses they raised. The group lived closer to Iṣfahān than to Fārs, but their leaders owned many estates and villages in Fārs (al-Ișțakhrī 1870, 145).

102 Al-Iștakhhrī 1870, 144. 
It is possibly in this context that his conflict with prominent family members, in particular with Abū Bilāl Mirdās, can be explained. Abū Bilāl is presented as a 'traditional' local lord: he was prepared to act on behalf of the caliphal authorities, but not to confront the military powers, sticking to paradigms of negotiation and mediation instead. When Ibn Wāṣil started to assert himself as head of the province, he must have felt threatened, as indeed he was. If he was a senior member of the senior branch of the family, he clearly stood in Ibn Wāṣil's way.

\section{Muḥammad b. Wāṣil in Earlier Scholarship}

Ibn Wāṣil is by no means an unknown figure. Since sources on his career have been readily available for a long time, it is no surprise that many earlier scholars have devoted lines or pages to him. In general, he appears as a lesser figure in the story of Ya'qūb b. al-Layth and therefore has not been the subject of a detailed study until now.

Nöldeke gives a brief rendering of the main source narrative in his study of the Șaffārids. He (wrongly) claims that Muhammad b. Wāṣil was already recognized as governor over Fārs by the caliphal administration in 256 H/861 CE during Ya'qūb’s advance, and again Ibn Wāșil appears as caliphal representative fighting Ya'qūb after the Șaffār had been defeated. In all, Ibn Wāṣil is not a prominent figure and not described as a rebel. ${ }^{103}$

Vasmer's study on the coinage of the Șaffārids and their enemies in Fārs and Khurāsān not only has basic numismatic information, but also a summary of the narrative in the main chronicles, much fuller than the one found in Nöldeke. Vasmer presents Ibn Wāșil as a powerful provincial figure, allied at some times to the caliphal side and at others to Ya'qūb. ${ }^{104}$

Bosworth strikes another note in his study on the armies of the Saffārids. He touches briefly on the conquest of Sa īdābād, Ibn Wāṣil's castle, by Ya'qūb’s troops in $263 \mathrm{H} / 876 \mathrm{CE}$, and comments that it "belonged to the adventurer Muhammad b. Wāṣil al-Ḥanẓalī.” In a footnote, he asks whether this man was "the Muhammad b. Wāṣil who had rebelled in Bust against the Ṭāhirid governor

103 Nöldeke 1892, 185-217 (193, 200, 203). Nöldeke does not quote his sources, but it is evident that his study is based on al-Tabarī, Ibn al-Athīr, and Ibn Khallikān. There is no trace of his having used al-Ișțakhrī (who is not a central source for the history of the Șaffārids).

104 Vasmer 1930. 
there." ${ }^{105}$ This is the first time that Ibn Wāșil is categorized: he is an adventurer, and it is possible that he is a Khärijite on top of that. One has to ask whether either of these identifications is plausible. In my view, the answer has to be negative.

Muhammad b. Wāșil of Bust is mentioned in the Tārīkh-i Sisstān (and apparently in no other source). His rebellion is dated to approximately $222 \mathrm{H} / 837 \mathrm{CE}$, or 33 lunar years before his Fārsī namesake makes his first appearance. In Bust, in the years preceding $222 \mathrm{H}$ there had been several movements the Tärīkh-i Sisstān classifies as uprisings, all with a more or less clear Khārijite background. In $220 \mathrm{H} / 835 \mathrm{CE}$, famine broke out due to the drying up of the Helmand river and an uprising took place. Its leader was one 'Abdallāh al-Jabalī, and many Khārijites gathered around him. After some fighting the revolt was ended, not by a massacre but by some kind of agreement: 'Abdallāh was even given a robe of honor. Another uprising took place under Muhammad b. Yazīd; the source says that many of those who had dispersed (probably out of the Khārijites) gathered again. This revolt was quelled by the military and many people were killed. After further actions, the Khārijites (or at least a substantial number of them) left for Kirmān. Again, the governor did not succeed in establishing his rule at Bust on behalf of the Țāhirids; again, there was an uprising, this time under Muhammad b. Wāșil, and again, those who had previously dispersed gathered around him. (This reference to people who had earlier dispersed prompts thoughts of a Khārijite background.) Muhammad b. Wāșil succeeded in taking the new governor prisoner for a while, but the movement was quickly subdued. ${ }^{106}$ We do not hear anything more of this Muhammad b. Wāșil in the context of Bust or of Sisstān in general. Should the two men be identified, as Bosworth suggests?

Bust is situated in present-day Afghanistan ${ }^{107}$ in the Helmand valley, and is roughly 1,500 km (by modern road) away from Iștakhr in Fārs. It belonged to Sīstān, where Khārijī movements were frequent and occurred even when Khārijism was largely extinct elsewhere. And there is not the slightest hint that Muhammad b. Wāṣil al-Ḥanẓalī of Fārs ever travelled to Sīstān, let alone led an uprising there. The time difference of 33 lunar years also speaks against this identification, if it does not preclude it.

105 Bosworth 1968, 534 -554 (551), with note 75. This note has elicited a comment by L. P. Smirnova in Istoriia Sistana 1974, p. 432, note 543. Smirnova claims that al-Ṭabarī has Muhammad b. Wāṣil as a Kurdish leader from Fārs (al-Ṭabarī has nothing of the sort). She then quotes Bosworth's attempt to identify this person with Muhammad b. Wāṣil of Bust without taking a clear position.

106 Tārīkh-i Sīstān 1314/1935, 185-188, Istoriia Sistana 1974, 192-193.

107 Present-day Lashkargāh-i Bāzār, see Fischer / de Planhol. 
Regarding the argument of Khārijism, as I have shown above the Hanẓali family of Fārs had a prominent record of Khārijism but their ancestors were quietists. Moreover, the family may have opted out before the early $9^{\text {th }}$ century. A Khārijite past is no argument for a Khārijite present in the times of Muhammad b. Wāṣil. The Khārijite argument regarding Muhammad b. Wāṣil of Fārs was not prominent before Shaban's Islamic History of 1976. In an altogether inadequate summary of events in Fārs, he states: "It is a remarkable fact that Muhammad b. Wāṣil was of a genuine lineage of Umayyad Khārijites who had long since settled in Ișțakhr in the heart of Fārs." ${ }^{108}$ This is correct, as we have seen, but it does not mean what Shaban apparently wants us to believe, namely that Muhammad b. Wāṣil was a Khārijite or a crypto-Khārijite or something of the sort, and that Khārijism was a synonym for revolt and rebellion.

Shaban's statement was taken up by Bosworth in his monograph on the History of the Saffärids and the Maliks of Nimruz. In this work, Bosworth quotes the early Khārijite connections of the family but does not claim that Muhammad b. Wāṣil himself had Khārijite leanings, and he does not come back to the question of whether the man in Sīstān should be identified with the man in Fārs. This book's passage on Fārs during the three-cornered struggle between the caliphal forces, the Șaffār, and Muhammad b. Wāṣil is otherwise an excellent summary of what the sources tell us. ${ }^{109}$

In Kennedy's textbook on the history of the caliphate, Ibn Wāșil is briefly mentioned. Kennedy follows Bosworth: Ibn Wāṣil is “a local adventurer”. He establishes a context for Ibn Wāṣil's movement and the caliphal policies in the context of the revolt of the Zanj in southern Iraq, and indeed we have seen that all the military commanders who came to Fārs to fight Ibn Wāṣil were otherwise engaged in this struggle. ${ }^{110}$

Gordon follows the general trend in his work on the military slaves (where, of course, the focus is not on Fārs). Tracing the career of the slave general Mūsā b. Bughā, he notes that Mūsā's forces (under the command of 'Abd al-Rahmān b. Muflị) were defeated by "local rebel” Ibn Wāșil. ${ }^{111}$

Deborah Tor has most to say on the subject: she sees the Muhammad b. Wāṣil in Bust as the same person as the Muhammad b. Wāṣil in Fārs, and therefore she can state that when Ibn Wāṣil usurped the province (Fārs) in 256 H/870 $\mathrm{CE}$, he "had a long history of disruptive behavior." She also calls him an "erst-

108 Shaban 1976, 98-99.

109 Bosworth 1994, 147-152.

110 Kennedy 2016, 153.

111 Gordon 2001, 145. 
while Khārijite” or an "at least erstwhile Khārijite” as indeed he was if he was the rebel of Bust. She does not note his background as one of the mulūk Fārs, nor mention the family's Khārijite antecedents. ${ }^{112}$ When she describes Ya'qūb's later campaign against Ibn Wāșil that ended with the former's victory, she tells us that "at this juncture one of the leading magnates of Fārs appealed to Ya'qūb to save Fārs from the arbitrary rule of Muhammad b. Wāṣil.” She omits that this magnate, Abū Bilāl Mirdās, was a relative of Muhammad's, and she does not give details as to how Ibn Wāșil's rule was arbitrary. ${ }^{113}$ Her picture of Ibn Wāṣil as a Khārijite with a long record of disruptive behavior is therefore based on an identification I think is spurious, and in order to make this dubious identification work she has to disregard all other information about Ibn Wāșil's background. Moreover, the identification of Khārijism with "disruptive behavior" does not do justice to the quietist (and later Ibādī) movement current in Khārijism.

I hope this essay has shown that Muhammad b. Wāṣil was neither a Khārijite (if that means an irredeemable rebel) nor an adventurer. He may have been a rebel in that he 'usurped' power in Fārs, but at times he also was the appointed governor there on behalf of Ya'qūb or the caliph. He was a representative of the mulūk Fārs, interested in safeguarding his influence, wealth, and power. Earlier research has more or less completely disregarded his family history (with only an occasional hint at its early Khārijite stages) as well as his social standing. This is a consequence of the central perspective taken by most researchers, to whom locally powerful people appear as rebels as soon as they come into conflict with the imperial center, and outright rebellion starts as soon as these local powerholders take action in defense of their own interests against the central powers. Let it be noted, however, that Bosworth came back to this question in one of his latest publications, and that in his entry "Șaffārids" in the Encyclopedia Iranica Online he calls Muhammad b. Wāṣil a "local magnate”. ${ }^{114}$ This coincides with the results of the present analysis.

112 Tor 2007, 130-131.

113 Tor 2007, 157.

114 Bosworth, "Șaffārids.” 


\section{Bibliography}

\section{Primary Sources}

al-'Awfī, Sadīd al-Dīn Muḥammad (1393 H/2015 CE), Jawāmi' al-ḥikāyāt wa-lawāmi` al-riwāyāt, part 1, chapter 12-14, ed. by Amīr Bānū Muṣaffā (Karīmī), Tehran: Pazhūhishgāh-i 'ulūm-i insānī wa-muțāla'āt-i farhangī.

al-Balādhurī, Ạ̣mad b. Yaḥyā (2000), Ansāb al-ashrāf, ed.by Maḥmūd al-Firdaws al-'Aẓm, vol. 11, Damascus: Maktabat al-yaqża al-'arabiyya.

Daylamī, Abū l-Ḥasan (1955), Sīrat al-shaykh al-kabīr Ibn Khafĩf, ed. by Annemarie Schimmel, Ankara: Ankara İlahiyat Fakültesi.

al-Ḥillī, Abū l-Baqā (1984), al-Manāqib al-Mazyadīya fĩ akhbār mulūk al-Asadīya, ed. by S.

Mūsā Darādika and M. Khuraysāt, Amman: Maktabat al-risāla al-ḥadītha.

Ḥudūd al-'ālam (1962), ed. by M. Sutūda, Tehran: Dānishgāh-i Tihrān.

Ibn al-Athīr, 'Izz al-Dīn 'Alī (1965), al-Kāmil fĩ l-ta'rīkh, ed. by Carl J. Tornberg, vol. 7, reprint, Beirut: Dār Bayrūt.

Ibn al-Balkhī (1921), Fārsnāma, ed. by Guy Le Strange / Reynold Nicholson, London: Luzac.

Ibn Funduq Bayhaqī, 'Alī b. Zayd (1317 H/1938 CE), Tārīkh-i Bayhaq, ed. by Aḥmad Bahmanyār, Tehran: Furūghī.

Ibn Ḥawqal, Abū l-Qāsim b. 'Alī (1939), Kitāb Șūrat al-arḍ, ed. by J. H. Kramers, Leiden: Brill; French translation: J. H. Kramers / G. Wiet (1964), Configuration de la terre, Beirut: Commission internationale pour la traduction des chefs-d'œuvre.

Ibn Khallikān, Abū l-'Abbās Ạ̣mad (1367 H/1948 CE), Wafāyāt al-a'yān, ed. by Muhyī al-Dīn 'Abd al-Ḥamīd, vols. 4-5, Cairo: Maktabat al-nahḍa al-mișriyya.

Ibn Khurdādhbih, Abū l-Qāsim 'Ubaydallāh (1889), Kitāb al-Masālik wa-l-mamālik, ed. by M. J. de Goeje, Leiden: Brill.

Ibn Miskawayh, Aḥmad b. Muḥammad (1916), Tajārib al-umam, ed. by Henry Frederick Amedroz, Cairo: Sharikat al-tamaddun al-șināiyya.

Ibn al-Mu'tazz, Abū l-'Abbās 'Abdallāh (1939), Ṭabaqāt al-shu'arā' fĩ madḥ al-khulafä' wa l-wuzarā', ed. by 'Abbās Iqbāl, London: Luzac.

Ibn al-Nadīm, Muḥammad b. Isḥāq (n.d.), Kitāb al-Fihrist, ed. by Reza Tajaddod, Tehran: Marvi.

al-Ișțakhrī, Abū Isḥāq Ibrāhīm (1870), Kitāb al-Masālik wa-l-mamālik, ed. by M. J. de Goeje, Leiden: Brill.

al-Khațīb al-Baghdādī, Abū Bakr Aḥmad b. 'Alī (1931), Ta'rīkh Baghdād, vol. 6, Cairo: Maktabat al-khānjī.

al-Khwārazmī, Abū 'Abdallāh (1895), Mafātīh al-'ulūm, ed. by Gerlof van Vloten, Leiden: Brill. al-Kūfī, Muḥammad b. Aḥmad Ibn A'tham (1392 H/1972 CE), Kitāb al-Futūḥ, vol. 6, ed. by Muḥammad 'Abd al-Mu'īd Khān, Hyderabad/D.: Maṭba'a al-'uthmāniyya.

Māfarrūkhī, Mufaḍ̣̣al b. Sa'd (1933), Kitāb Maḥāsin Iṣfahān, ed. by J. Tihrānī, Tehran: Mațba'a-yi majlis.

al-Mas'ūdī, 'Alī b. al-Ḥusayn (1962), Les Prairies d'Or, French translation by Pavet de Courteille and Barbier de Meynard, Paris: Geuthner.

al-Muqaddasī, Shams al-Dīn Abū 'Abdallāh Muḥammad b. Aḥmad (1906), Kitāb Ạ̣san al-taqāsīm fĩ ma'rifat al-aqālīm, ed. by M. J. de Goeje, Leiden: Brill. 
al-Sam'ānī, 'Abd al-Karīm (1963), al-Ansāb, vol. 2., ed. by 'Abd al-Raḥmān al-Mu'allimī, Hyderabad/D.: Maktabat al-dā'irat al-'uthmāniyya.

al-Ṭabarī, Abū Ja'far Muḥammad b. Jarīr (1994), Ta'rīkh al-umam wa-l-mulūk, ed. by

Muḥammad Abū l-Fạ̣l Ibrāhīm, Beirut: Rawā'i‘ al-turāth al-'arabī [reprint of the Cairo edition 1967].

Tārīkh-i Sīstān (1314 H/1935 CE), ed. by Malik al-Shu'arā Bahār, Tehran: Mu'assasa-yi khāwar; Russian translation: smirnova, Lidiia Pavlovna (1974), Istoriia Sistana, Moscow: Nauka. al-'Utbī, Abū Nașr Muḥammad b. 'Abd al-Jabbār (1424 H/2004 CE), al-Yamīnī, ed. by lṇsān Dhūnūn al-Thāmirī, Beirut: Dār al-țalī'at li-l-țibā'a wa-l-nashr.

Yāqūt al-Rūmī, Ibn 'Abdallāh (1955), Mu'jam al-buldān, vol. 1, Beirut: Dār șādir.

\section{Studies}

Bosworth, Clifford Edmund (1968), "The Armies of the Șaffārids", Bulletin of the School of Oriental and African Studies 31/3: 534-554.

Bosworth, Clifford Edmund (1994), The History of the Saffarids of Sistan and the Maliks of Nimruz (274/861 to 949/1542-3), Costa Mesa: Mazda Publishers.

Bosworth, Clifford Edmund, "Dayral-'Āqūl”, www.iranicaonline.org/articles/dayr-al-aqul (accessed Feb. 7, 2017).

Bosworth, Clifford Edmund, "Ebn al-Balkī”, www.iranicaonline.org/articles/ebn-al-balki (accessed Feb. 7, 2017).

Bosworth, Clifford Edmund, "Ṣaffārids”, www.iranicaonline.org/articles/saffarids (accessed Feb. 11, 2017).

Bulliet, Richard (1972), The Patricians of Nishapur, Cambridge (Mass.): Harvard University Press.

Cohen, H. J. (1970), “The Economic Background and the Secular Occupation of Muslim Jurisprudents and Traditionists in the Classical Period of Islam (until the Middle of the Eleventh Century)", Journal of the Economic and Social History of the Orient 13: $16-61$.

Durand-Guédy, David (2010), Iranian Elites and Turkish Rulers. A History of Ișfahān in the Saljūq Period, London: Routledge.

Fischer, Klaus / de Planhol, Xavier, "Bost”, www.iranicaonline.org/articles/bost (accessed Feb. 7, 2017).

Gaiser, Adam (2014) "Tracing the Ascetic Life and Very Special Death of Abū Bilāl: Martyrdom and Early Ibadi Identity", in: Angeliki Ziaka, ed., On Ibadism, Hildesheim: Olms, 59-72.

Gelvin, James L. (2006), “The 'Politics of Notables' Forty Years After”, MESA Bulletin 40/1: $19-29$.

Gordon, Matthew (2001), The Breaking of a Thousand Swords. A History of the Turkish Military of Samarra (A.H. 200-275/815-889 C.E.), Albany, NY: SUNY Press.

Hagemann, Hannah (2016), "Challenging Authority: al-Balādhurī and al-Ṭabarī on Khārijism during the Reign of Mu'āwiya b. Abī Sufyān”, al-Masāq 28/1: 36-56.

Hayes, Edmund (2015), "The Death of Kings: Group Identity and the Tragedy of Nezhād in Ferdowsi's Shahnameh”, Iranian Studies 48/1, 1-25.

Hourani, Albert (1981), "Ottoman Reform and the Politics of Notables", reprinted in Hourani, The Emergence of the Modern Middle East, London: Macmillan, 36-66. 
Humphreys, Stephen (1991), Islamic History. A Framework for Inquiry, rev. ed., Princeton: Princeton University Press.

Karev, Yury (2015), Samarqand et le Sughd à l'époque 'abbāside, Paris: Association pour l'avancement des études iraniennes.

Kennedy, Hugh (2016), The Prophet and the Age of the Caliphates, Third Edition, London: Routledge.

Levi della Vida, Giorgio (1993), “Mirdās b. Udayya”, The Encyclopaedia of Islam, 2nd ed., vol. 7, 123-124.

Levi della Vida (2004), Giorgio, “Salmān al-Fārisī”, The Encyclopaedia of Islam, 2nd ed., Supplement, 701-702.

Marlow, Louise (2016), Counsel for Kings. Wisdom and Politics in Tenth-Century Iran. Volume I: The Nașīhat al-mulūk of Pseudo-Māwardī. Contexts and Themes, Edinburgh: Edinburgh University Press.

Morony, Michael (1984), Iraq after the Muslim Conquest, Princeton: Princeton University Press.

Mottahedeh, Roy (1973), “Administration in Būyid Qazwīn”, in: Donald Sidney Richards, ed., Islamic Civilisation, 950-1150, Oxford: Cassirer, 33-45.

Mottahedeh, Roy (1975), "Review of Bulliet (1972)", Journal of the American Oriental Society 95/3: 491-5.

Nöldeke, Theodor (1892), “Jakob der Kupferschmied und seine Dynastie”, in Theodor Nöldeke, Orientalische Skizzen, Berlin: Paetel, 185-217.

Oberling, Pierre / Hourcade, Bernard, “'Arab iv. Arab tribes in Iran”, www.iranicaonline.org/ar ticles/arab-iv (accessed Feb. 7, 2017).

Paul, Jürgen (1994), “Nachrichten arabischer Geographen aus Mittelasien”, in: Bert Fragner and Birgitt Hoffmann, eds., Bamberger Mittelasienstudien, Berlin: Klaus Schwarz, $179-191$.

Paul, Jürgen (2013), “Where did the dihqāns go?”, Eurasian Studies 11: 1-34.

Paul, Jürgen (2015) "Local Lords or Rural Notables? Some Remarks on the ra'īs in Twelfth Century Eastern Iran”, in: Andrew Peacock and Deborah Tor, eds., Medieval Central Asia and the Persianate World. Iranian Tradition and Islamic Civilisation, London: Tauris, $174-209$.

Paul, Jürgen (2016), Lokale und imperiale Herrschaft im Iran des 12. Jahrhunderts. Herrschaftspraxis und Konzepte, Wiesbaden: Reichert.

Pellat, Charles (2004), “Dīkdān”, The Encyclopaedia of Islam, 2nd ed., Supplement, $222-223$.

Popovic, Alexandre (2002), “Zandi”, The Encyclopaedia of Islam, 2nd ed., vol. 11, 445-446.

Pourshariati, Parvaneh (2011), Decline and Fall of the Sasanian Empire. The Sasanian-Parthian Confederacy and the Arab Conquest of Iran, London: Tauris.

al-Qāḍī, Wadād (2009), "In the Footsteps of Arabic Biographical Literature: a Journey, Unfinished", Journal of Near Eastern Studies 68/4: 241-252.

Shaban, M. A. (1976), Islamic History. A New Interpretation, vol. 2, Cambridge: Cambridge University Press.

Shahbazi, Shapur, "Hormozān”, www.iranicaonline.org/articles/hormozan (accessed Feb. 7, 2017).

Spuler, Bertold (1952), Iran in frühislamischer Zeit, Wiesbaden: Steiner. Tafażżoli, Ahmad, "Dehqān”, www.iranicaonline.org/articles/dehqan (accessed Feb. 7, 2017). 
Tor, Deborah (2007), Violent Order: Religious Warfare, Chivalry, and the 'Ayyār Phenomenon in the Medieval Islamic World, Istanbul \& Würzburg: Ergon in Kommission.

Treadwell, Luke (2003), "Shāhānshāh and al-Malik al-Mu'ayyad: The Legitimation of Power in Sāmānid and Būyid Iran”, in: Farhad Daftary and Josef W. Meri, eds., Culture and Memory in Medieval Islam, London: Tauris, 318-337.

de la Vaissière, Étienne (2007), Samarcande et Samarra. Elites d'Asie centrale dans l'empire abbaside, Paris: Association pour l'avancement des études iraniennes.

van Ess, Josef (1992), Theologie und Gesellschaft im 2. und 3. Jahrhundert Hidschra. Eine Geschichte des religiösen Denkens im frühen Islam, Bd. 2, Berlin: De Gruyter.

van Renterghem, Vanessa (2015), Les élites bagdadiennes au temps des Seldjoukides. Étude d'histoire sociale, 2 vols., Beirut/Damascus: Presses de l'IFPO.

Vasmer, Richard (1930), “Über die Münzen der Șaffāriden und ihrer Gegner in Fārs und Hurāsān”, Numismatische Zeitschrift. Neue Folge 23/63: 131-162.

Wilkinson, J. C. (1975), “The Julandā of Oman”, Journal of Oman Studies 1: 97-108. 